\title{
THE DEVELOPMENT STRATEGY OIL PALM-CATTLE INTEGRATION IN BIREUEN DISTRICT ACEH PROVINCE
}

\author{
T.M. Nur ${ }^{*}$, Halus Satriawan ${ }^{* * * * * *)}$, Chairul Fadli ${ }^{* * *}$, Ernawita $^{* *)}$ \\ ${ }^{*}$ Department of Agribusiness, Faculty of Agriculture, Almuslim University \\ Jl. Almuslim Matangglumpangdua, Peusangan, Bireuen, Aceh 24261, Indonesia \\ ${ }^{* *}$ Department of Agrotechnology, Faculty of Agriculture, Almuslim University \\ Jl. Almuslim Matangglumpangdua, Peusangan, Bireuen, Aceh 24261, Indonesia \\ ${ }^{* * *}$ Department of Animal Husbandry, Faculty of Agriculture, Almuslim University \\ Jl. Almuslim Matangglumpangdua, Peusangan, Bireuen, Aceh 24261, Indonesia \\ ${ }^{* * * *}$ Magister Program in natural resource and environmental management, Almuslim University \\ Jl. Almuslim Matangglumpangdua, Peusangan, Bireuen, Aceh 24261, Indonesia
}

\begin{abstract}
Environments in which oil palms grow involve some components and production resources crucial in increasing the development of integrated palm oil plantation systems without damaging the environment. This study aimed to determine strategies and direction of the development of oil palm-cattle integration and improve the regional economy. The primary data were obtained through questionnaires by interviewing 50 respondents, which comprised cattle farmers and experts /stakeholders of Almuslim University and STIE Kebangsaan Bireuen and local government agencies directly involved with the study topics. AHP and SWOT were used to analyze oil palm-cattle integration strategy development data. The main findings of the study require main strategies: 1) Increasing the efficiency of oil palm-cattle integration from extensive to intensive model with the support of stakeholders; 2) Creating an effective and successful pilot cattle farmer groups in carrying out oil palm-cattle integration by utilizing cheap and nutritious feed from oil palm plantations; 3 ) Utilizing cow dung as fertilizer and biogas as a source of income for farmers; 4) Expanding cattle farmer's knowledge on the development of beef cattle population and livestock health services; 5) Increasing active government participation in facilitating cattle and oil palm farmers in integration implementation, and 6) Utilizing financial institutions/banking services to increase business capital which will aid in increasing beef cattle population and oil palm production.
\end{abstract}

Keywords: AHP-SWOT, plantation, stakeholders, oil palm, cattle

\begin{abstract}
Abstrak: Lingkungan tumbuh kelapa sawit melibatkan beberapa komponen dan sumber daya produksi yang sangat penting untuk meningkatkan pengembangan kelapa sawit terintegrasi tanpa merusak lingkungan. Penelitian ini bertujuan menentukan strategi dan arah pengembangan integrasi kelapa sawit-sapi yang dapat meningkatkan perekonomian daerah. Data primer diperoleh melalui kuesioner dan wawancara dengan 50 orang peternak sapi dan pakar/stakeholder. Pakar terdiri dari akademisi dari perguruan tinggi (2 orang dari Universitas Almuslim, 1 orang dari STIE Kebangsaan Bireuen). Selain itu pakar juga dilibatkan dari Dinas Pertanian dan Perkebunan, Dinas Peternakan dan Kesehatan Hewan, Dinas Lingkungan Hidup dan Kehutanan serta Badan Perencanaan Pembangunan Daerah. Analisis data untuk pengembangan strategi integrasi kelapa sawit-sapi menggunakan AHP-SWOT. Temuan penting yang diperoleh dalam penelitian ini membutuhkan strategi utama: 1) Meningkatkan efisiensi model integrasi kelapa sawit-sapi dari ekstensif menjadi intensif dengan dukungan pemangku kepentingan; 2) Menciptakan kelompok peternak percontohan yang efektif dan berhasil dalam melakukan integrasi kelapa sawit-sapi dengan memanfaatkan pakan murah dan bergizi dari perkebunan kelapa sawit; 3) Memanfaatkan kotoran sapi sebagai pupuk dan biogas sebagai sumber pendapatan petani; 4) Peningkatan SDM peternak untuk pengembangan populasi sapi potong dan pelayanan kesehatan ternak; 5) Meningkatkan peran aktif pemerintah untuk memfasilitasi peternak sapi dan pengusaha perkebunan dalam melaksanakan integrasi; dan 6) Memanfaatkan lembaga keuangan/jasa perbankan untuk meningkatkan modal usaha yang akan membantu peningkatan populasi sapi potong dan produksi kelapa sawit.
\end{abstract}

Kata kunci: AHP-SWOT, plantation, stakeholders, kelapa sawit, sapi

\footnotetext{
${ }^{1}$ Corresponding author:

Email: satriawan_80@yahoo.co.id
} 


\section{INTRODUCTION}

Meat is an excellent protein source and iron source in hemoglobin formation, often used as an indicator of living standards between countries. Indonesia's meat consumption is relatively low (1.77 kg capita- 1 year-1) compared to other southeast Asian countries such as the Philippines (7.5 kg), Singapore and Malaysia $(15 \mathrm{~kg})$. Low beef consumption in Indonesia is due to limited cattle population, thus, resulting in high beef market prices. It is estimated that to meet the beef demands in the Indonesian market, by 2020 , Indonesia still has to import the beef from other countries (Silalahi et al. 2019). In 2019 , as much as 59,472 tons or $10.38 \%$ of beef were imported with a total production target of 572,850 tons (Ministry of Agriculture, 2015). Hence, increasing the cattle population, which will invariably increase beef consumption, is needed to increase oil palm-cattle integration.

Bireuen is one of the districts in Aceh which contributes greatly to the agricultural sector to the GRDP. Bireuen's contributes to a total of $3.98 \%$ GRDP yearly. Therefore, it means that the agricultural sector is an influential economic sector in Bireuen. Plantation and livestock are the two largest sub-sectors in the formation of GRDP in the agricultural sector. Aceh Province has an oil palm cultivation area of 393,230 ha; $50.41 \%$ are community-owned plantations, while $49.59 \%$ of the total area are large plantations (state and private). Furthermore, the total area covered by small-scale oil plantations in Bireuen is 3,109 hectares (BKPM, 2015). Bireuen is also recognized as one of the cattle breeding centers in Aceh, with a cattle population in 2014 of 413,560 . Bireuen contributes to $13.32 \%$ of the total cattle population in Aceh Province.

One limiting factors in meat production is land (Gutiérrez-Vélez et al. 2011; Lerner et al. 2017). But it can be countered by an integrated system with plantation crops (Latif and Mamat, 2002). Traditionally, mixed farming has been the primary agricultural system practiced by smallholders in Asia, especially Malaysia (Rahman et al. 2018) and Indonesia (Matondang and Talib, 2015), to improve total beef production. Input and output of the crop and animal enterprises are integrated inextricably in these systems, depending upon the available resources (Paris, 2002; Martin et al. 2015). Oil palm is one of the plantation crops potential to develop an integrated system (Devendra, 2004). The integration of oil palm into cattle raising will benefit the oil palm industry and cattle ranching because it will increase the intensity of land use and at the same time reduce the costs of maintaining oil palm (Devendra, 2011), increase farmers' income, boost the rural economy (Hanifah and Wasito, 2018), reduce the need for chemical herbicides, and provide additional food security, ecosystem services, and habitat heterogeneity (Tohiran et al. 2019). In Indonesia, ruminant-oil palm plantation integration is one of the agricultural practices, which commonly applied since the introduction of a "Sistem Integrasi Sapi Kelapa Sawit" (SISKA) or "System Integration Cattle -Oil Palm Plantations" in 2011 (Henuk et al. 2018). Therefore, integration of oil palm - livestock (cattle) seems to be the best option for the modern agriculture system (Lim et al. 2019). According to De Pinto et al. (2016), livestock can reduce carbon emissions in an oil palm plantation environment. Henson et al. (2012) reviewed the environmental impacts of oil palm plantations and concluded that the activity posed no environmental threat.

The main problem associated with oil palm cultivation is mainly during the land opening and clearing step of land preparation, which disturbances local biodiversity. However, the positive influence of integrating oil palmcattle (ruminants) includes some beneficial interactions of plant-animal-soil. In this context, oil palm (far more than other tree crops) provides significant benefits for developing an integrated system, especially as a source of food (Paris, 2002; Jalaludin, 2018). Gabdo and Ismail (2013) reported that livestock with an integrated system contributes significantly to oil palm production by reducing costs and maximizing land use. This system has produced more palm oil, generating more income for Bireuen (Gabdo and Ismail, 2013). The oil palm-cattle integration program in Bireuen is the government's commitment to the RPJMN mandate of the 2015-2019 Strategic Plan. This program was achieved through the Directorate General of Livestock and Animal Health's 2014 Livestock Area Development program.

With regards to the challenges and obstacles associated with the oil palm - ruminants integration system, Devendra (2009) identified several things that led to the low adoption of this system, as inadequate awareness of the integration system such as oil palm and ruminants; resistance from plant-oriented plantation sectors; inadequate technology applications; high prices for crude palm oil production which leave plantation owners to emphasize palm oil production; 
an unattractive investment climate; weak inter-agency collaboration; and the absence of the right policy to encourage an integrated system.

On the other hand, Utoma and Widjaja (2012) stated that integration of oil palm - ruminants give rise to three integrated activities simultaneously, namely 1) cattle feed industry based on oil palm plantations by-products, 2) cow-calf operation, and 3) cattle fattening. Feed resource potency from the oil palm industry comprises leaf and oil palm midribs as a primary fibre source and palm oil processing products such as solid ex-decanter and palm kernel as protein sources. Thus, to implement the plan in Bireuen, integration planning considering opportunity aspects, challenges, and resistance is critical to conduct. This study aims at determining the right strategy and direction of the development of the oil palm-cattle integration, thereby improving the regional economy of the Bireuen Regency.

\section{METHODS}

The research was conducted in Bireuen District in Aceh Province. Geographically, Bireuen is located at 4 $\circ 54^{\prime}-5^{\circ} 21$ 'North Latitude and $96^{\circ} 20^{\prime}-97^{\circ} 21$ 'East Longitude and has a total area of $1,901.21 \mathrm{~km}^{2}$. Bireuen consists of 17 subdistricts and the study was carried out in Peusangan Siblah Krueng, South Peusangan, Juli and Makmur Subdistrict. The location was chosen due to the fact that the integration of oil palm cattle at the farmer level had previously been carried out in these districts.

Primary data and secondary data were used in this study. Sample determination was conducted using purposive sampling, considering that the selected samples owned minimal 1 hectares of oil palm plantations and reared at least 2 (two) castles in an integrated system.

The primary data were obtained through questionnaires and interviewing 50 cattle farmers and experts/ stakeholders. Experts are constitute of academics of Almuslim University ( 2 experts) and STIE Kebangsaan Bireuen (1 expert); civil servants of Dinas Pertanian dan Perkebunan, Dinas Peternakan dan Kesehatan Hewan, Dinas Lingkungan Hidup dan Kehutanan, and Badan Perencanaan Pembangunan Daerah. In each agency, one expert was chosen with an agriculture or animal husbandry academic background, and current responsibilities in the agency are suitable for our study topics. Secondary data was obtained from the Aceh Province BPS, BPS Bireuen District, Aceh Province Plantation Service Aceh Province Animal and Animal Health Service, the Bireuen District Animal Husbandry Service Bireuen District Forestry and Plantation Service. Secondary data was also obtained from previous research work related to the subject matter.

The oil palm-cattle integration strategy development uses AHP-SWOT to analyze the collected data. Strength Weaknesses Opportunities Threats (SWOT) analysis systematically identifies various factors to formulate a development strategy. This analysis is based on the logic that maximizes the strengths and opportunities and simultaneously minimizes weaknesses and threats.

Based on Figure 1, the main objective of this study is to establish a strategy of development of oil palmcattle integration through monitoring and analysis of strengths, weakness, opportunity, and threats (SWOT) of integration practices oil palm-cattle Bireuen district. The application of SWOT matric intended to aid adaptation between strength and opportunity (SO strategy), strength and threat (ST strategy), weakness and opportunity (WO strategy), weakness and opportunity (WO strategy), and weakness and threat (WT strategy). After determining alternative strategies, the AHP method is used to prioritize these alternatives, then, to prioritize those alternatives used the AHP method. The method would result in the best strategy of various alternative strategies recommended by SWOT matric.

\section{RESULTS}

\section{Respondent Characteristics}

Most farmer respondents are high school graduates (58\%) with 11-30 years of experience in agriculture/ plantation/farming activities (80\%). It is interesting to note that $5 \%$ of the respondents are bachelor degree holders, and the main occupation is civil servants. This points out that agriculture/farming activity is also an interesting choice for those with higher education. Detail of respondent characteristits in Figure 2. 


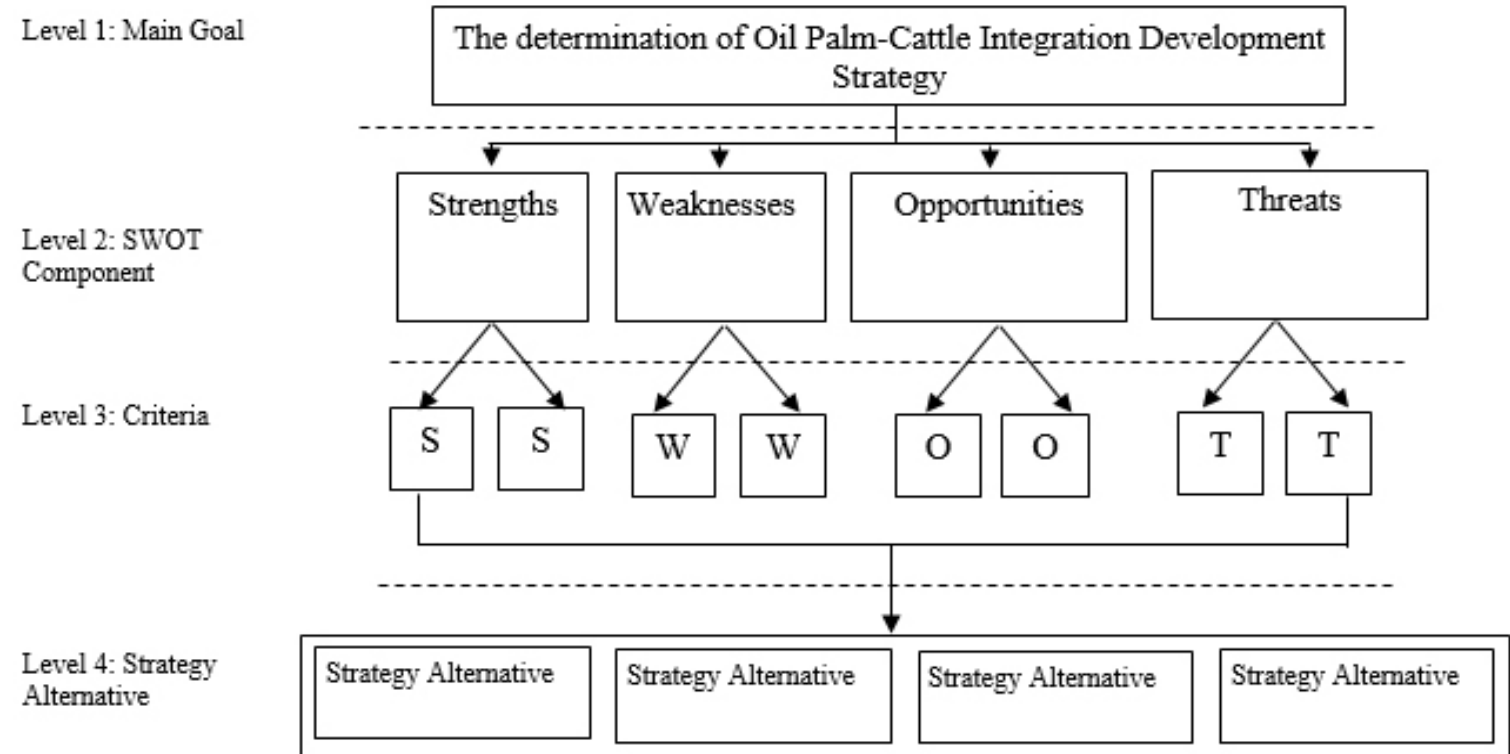

Figure 1. Hierarchy of palm-cattle integration development analysis with AHP-TOPSIS
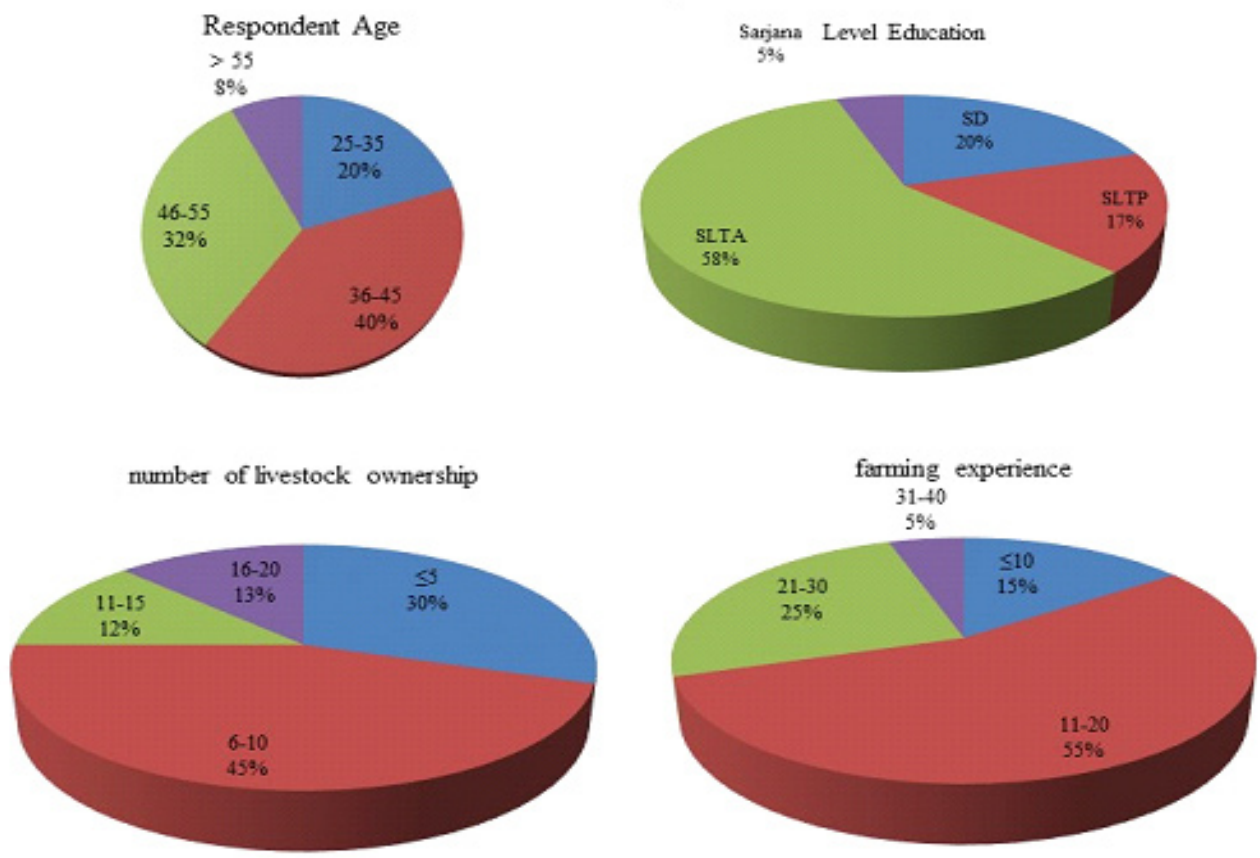

Figure 2. Respondent characteristits

\section{Identification of Internal and External Factors}

The results obtained from the SWOT analysis are used to maintain strength and increase profits in terms of current opportunities while reducing existing deficiencies and avoiding threats. Firstly, the various factors (internal and external factors) influencing the development of palm-cattle integration in Bireuen were identified, as displayed in Table 1.

\section{Internal Factors}

Some Internal Factors (Strengths) which strengthens the development of oil palm-cattle integration in Bireuen Regency are as follows:

Availability of Livestock Integration Practices in the Garden

Farmers in several areas in Bireuen have carried out the integration of cattle rearing in oil palm plantations. 
Currently, farmers freely let the cattle forage greens (grass/weeds) and palm fronds in plantations. As a result, livestock looks relatively thin because their nutritional needs are not met. Here, the farmer's main objective is only to maintain cattle rearing without considering its nutritional needs.

\section{Availability of Oil Palm Land}

The area used for oil palm plantations in Bireuen ranks sixth after Aceh Singkil District, East Aceh, South Aceh, West Aceh, Simeulue, out of 22 Regencies/ Cities in Aceh Province. The availability of cultivation land is an important factor in meeting the need for cattle feed with an integrated system. There is a more significant opportunity for the oil palm-cattle integration development to flourish in the Bireuen area by implementing extensive and intensive maintenance models. The farmer who desires to implement an integrated system supported by stakeholders will provide a promising added economic value from cattle rearing activity.

\section{Cattle Population}

The cattle populations in Bireuen in 2017 were 56,422 heads, while the cattle populations for Aceh Province were 511,362. Bireuen district supplies $11.03 \%$ of beef cattle for Aceh. The opportunity to increase the cattle population in the Bireuen district is still wide open with the oil palm-cattle integration program. The target is for the Bireuen district to become a center for beef cattle farming in Aceh Province in the nearest future. The integration program can increase the beef cattle population in correlation to the availability of oil palm plantation land.

\section{Cow Farmer Resources}

The next strength in integrating oil palm cattle is breeders' resources related to age, education and farming experience. Educated farmers between the ages of 25-55 years of sufficient experience will be easier to convince to accept innovation, utilize the principles of economies of scale and face business risks compared to those outside of this category. Therefore, they obtain a decent level of income and welfare. Farmers' resources will substantially influence the development of palm oil-cattle integration if they join farmers' groups. But, not all farmers/breeders were interested in joining the groups due to differences in each other needs. A similar result was found in Ghana's integration system, where the inputs significantly influenced small-ruminant farming outputs, herd size, capital, labour, feed, and veterinary expenses (Asante et al. 2017).

Table 1. Internal and external factors that affect the integration of oil palm-cattle

\begin{tabular}{|c|c|}
\hline \multicolumn{2}{|c|}{ Internal Factors } \\
\hline Strengths & Weakness \\
\hline $\begin{array}{l}\text { The practice of livestock integration in oil palm plantations } \\
\text { already exists } \\
\text { Availability of oil palm land } \\
\text { Cattle population } \\
\text { Resources for cattle farmers } \\
\text { Utilization of cow manure } \\
\text { Feed availability } \\
\text { Potency to increase farmer's income } \\
\text { Increase productivity } \\
\text { Decrease cost of production }\end{array}$ & $\begin{array}{l}\text { Farmer groups that focus on integration systems are very } \\
\text { limited } \\
\text { Land ownership by farmers } \\
\text { Cow rearing is extensive } \\
\text { Lack of knowledge and training Farmers had } \\
\text { Limited access to capital and credit from financial } \\
\text { institutions }\end{array}$ \\
\hline \multicolumn{2}{|c|}{ External Factors } \\
\hline Opportunity & Threat \\
\hline $\begin{array}{l}\text { Farmers are permitted to plant on lands } \\
\text { There is an artificial insemination program } \\
\text { The value of profits from oil palm-cattle Integration } \\
\text { Feed abundance as byproducts of the Oil palm plantations } \\
\text { Government policy support } \\
\text { Beef demand, especially during"festive" periods }\end{array}$ & $\begin{array}{l}\text { Limited oil palm plantation industry } \\
\text { Disease / reproductive disorders. } \\
\text { Reduced reproduction as a result of cutting. } \\
\text { Importation of beef } \\
\text { Business competition } \\
\text { Limited infrastructure development budget }\end{array}$ \\
\hline
\end{tabular}




\section{Utilization of Cow Manure}

The intensive integration implementation will produce more manure than extensive maintenance because livestock is always kept inside the cage, making manure collection easier. While in the extensive system, cattle manure can only be partially collected when inside the cage. When these excretes are released, they come in contact with the plant and become organic fertilizers. Generally, cattle will produce around $20-25 \mathrm{~kg}$ of dirt every day if they are grounded. If only grounded at night, dirt production is approximately $10 \mathrm{~kg}$. According to Mathius and Adiati (2013), every adult cow (weight $250 \mathrm{~kg}$ ) can excrete as much as $25.7 \mathrm{~kg}$ of fresh manure per day or 2,313 kg in 3 months with $468 \mathrm{~kg}$ of dry matter and nitrogen $14,866 \mathrm{~kg}$. This dirt is rich in organic matter and nutrients needed by the soil in recycling activities. Some of the Internal Factor Analysis (Weaknesses) associated with oil palm-cattle integration development in the Bireuen district are:

\section{Oil Palm-Cattle Integration System Efficiency is Low}

The cattle breeding model carried out by farmers is conducted on oil palm plantations. It might not be a problem if the plantation is privately owned, but if a state or private company owns the plantation, this will likely lead to conflict. In general, livestock grazed illegally on plantations will have a negative impact on the growth and production of oil palm. It defoliates the leaves, thereby increasing the period of immature plantations (PIP). In plants producing (PP) crops, these negative impacts are more diverse. Cattle are easy to reach midrib of young plants. It affects the decline in production due to decreased photosynthesis effectiveness, resulting in limited photosynthetic allocation for fruit development.

Cattle are carriers of Ganoderma boninense and bagworm disease (Metisa plana), diseases dangerous to oil palm plants. In addition, when livestock grazes freely on oil palm plantations, it damages the physical properties of the soil due to compaction and succession of weeds. According to Rahutomo et al. (2012), a large amount of livestock traffic on palm oil roots hampers the development of its roots. Therefore, cattle can be called a "pest" because of its negative impact on the growth and production of oil palm. A technical approach is not the only approach needed to handle this inconsistency properly. Social and economic aspects are also needed to reduce potential conflicts with residents around the plantation. It requires an alternative strategy to protect oil palm plants from cattle disturbance and provide the cattle development business opportunities.

The alternative handling is an intensive maintenance model. Animal feed is still taken from palm plantation waste such as midribs, palm kernel cake, and solid. Each maintenance model has its advantages and disadvantages. Animals that are caged gain more weight compared to those that grazed. Cattle are safer; feeding can be arranged according to the nutritional needs of cattle and the ease of collecting cattle manure. When these cattle gain the desirable weight, the sale value of livestock will increase, and this will, in return, increase farmers' income.

\section{Land ownership by farmers}

Based on data from BPS Aceh Province (2017), the area of smallholder oil palm plantations is 228,230 hectares, with a total of 109,075 people involved. This, therefore, means that the average land tenure is 2.09 ha. However, farmers in possession of plantation land are free to use their plantation land for grazing their livestock. Farmers who do not own plantations can make use of state-owned or private plantations. However, they should ensure they obtain a user permit before doing so. It is also cost-effective as farmers can make cages at the edges of oil palm plantations.

\section{Extensive and Semi-Intensive Cattle Maintenance}

In general, the maintenance model implemented by farmers is extensive. This model adopts the release of cattle on plantations. One of the benefits of using this technique is that farmers do not need to feed their livestock, as their livestock could graze and feed themselves. Additionally, this technique is cheaper. Farmers that make use of this technique tend to have lightweight livestock, which affects their sale value.

On the other hand, the semi-intensive maintenance system carries cattle grazing on oil palm plantations during the day and cages them at night. The release of livestock is carried out in the morning around 09.00. The advantage of using this technique is that cattle tend to have an adequate resting room to control their health. However, a significant drawback that tends to face by the farmer is the appropriate time to release their livestock. 
It was releasing livestock on oil palm plantations before sunshine made the cattle vulnerable to earthworms. Most farmers' shortcoming in intensive maintenance models usually occurs because the cattle must be fed, and it is costly to purchase concentrate feeds to increase the cattle's weight. This problem is faced in almost all location that develops integration systems in Indonesia (Silalahi et al. 2018).

\section{The lack of knowledge and training for farmers}

This is the most important farmer's weakness that government needs to pay adequate attention to. The weight score is 0.1 . A strategy should be put in place to ensure that participants get adequate training, especially in palm-cattle integration programs.

\section{Limited access to capital and credit from financial institutions}

Farmer as a group or as individuals has failed to get the benefit of many financial institutions. The main reason is that the breeder group is non-existent or lacks motivation and entrepreneurial spirit. Furthermore, most banking/financial institutions do not provide financial schemes to partner with farmers. In addition, farmers are in doubt to get help from financial institutions on the grounds of doubt about the potential failure of their business loans.

\section{External Factors}

External factors which are responsible for the development of palm-cattle integration in Bireuen are:

\section{Farmers get permission for plantation land}

In the research location, there was a plantation company supporting the oil palm-cattle integration model and giving permission to use plantation land to the farmer. This company implements Minister of Agriculture Regulation No. 105 / Permentan / PD.300 / 8 / 2014 in carrying out this procedure. This ministerial regulation aims at providing large oil palm plantation businesses and beef cattle business operators in integrating oil palm-cattle business with the benefits, integration, and sustainability approach.

\section{Availability of abundant feed on oil palm plantations}

The integration of livestock in oil palm is a form of mixed farming where two commodities can be synergized to utilize the same land optimally. If both commodities are appropriately integrated, they will contribute to sustainable food production systems. There are roughly 60 to 70 species of plants in oil palm plantations which consist of planted legume cover crops, naturally growing grasses, broad leaves, and ferns (Tohiran et al. 2017). They are considered as a weed that needs to be controlled periodically with chemical sprays or manual cutting. In addition, they are potential sources of food because of their yield, palatability, and nutritional value that are adequate for livestock. Under the right conditions and systematic management, livestock can effectively be used for weed control. The use of livestock to control biological weeds in oil palm plantations allows the formation of a harmonious relationship between livestock and oil palm (Ayob and Kabul, 2009).

Sunlight intensity of $40-60 \%$ through oil palm fronds is necessary for a reasonable amount of grass and other cover crops to develop under oil palm trees for cattle to graze comfortably. Cattle grazing is suitable even when the area has only $60-70 \%$ grass cover. Jusoh and Mamat (2002) stated many grass varieties contain nutrients comparable to commercially farmed grasses. The plant types usually available under oil palm trees are Ottochloa nodosa, Axonopus compressus, Mikania scandens and Asystasia intrusa.

\section{Artificial Insemination Program (AI)}

Data from the Development Division of Animal Husbandry Production and Development, Bireuen District Agriculture and Animal Husbandry Office noted that in 2015 the number of cattle treated by AI was as much as 5,905 with a total birth rate of 2,291 or about $60 \%$. This provides an opportunity for the expansion of the integration system between oil palm-cattle.

\section{Value of Advantages of Oil Palm-Cattle Integration}

Every effort made is to ensure that farmers make adequate profit. The farm analysis result showed that farmers' income with implementing an integration system ranged between $\mathrm{Rp} 7,520,160-10,436,580 /$ unit of livestock. The value of the profits will increase along with the increasing scale of maintenance and selection of quality breeds. 


\section{External Factor Analysis (Threats)}

\section{The lack of oil palm plantation industry}

The external factor which happens to be a threat in the development of oil palm-cattle integration is the lack of palm oil mills that produce palm oil waste. The number of palm oil mills in Bireuen is 2 (two) with machine capacity to process 20 tons of fresh palm fruit/hour and produces 5 tons of dry palm mud and 6 tons of dry palm kernel cake per day. If it is converted to the need for cattle feed, the capacity of one palm oil mill can comfortably meet the needs of 1,500 cows each year. The limitation in setting up a palm oil mill is the high cost of manufacturing factories, and to get profit is if the capacity (processing power) is above 30 tons of FFB per hour. Therefore, capital strength becomes the main thing in setting up the factory Palm oil (Martin et al. 2015).

\section{Reproductive Disorders}

Another external factor that poses a threat is the presence of diseases/reproductive disorders. The diseases associated with cattle rearing include diarrhea, tympani disease, inflammation of the spleen, intestinal worms, dermatitis, pneumonia, mineral deficiencies, and others. Reproductive disorders will also delay reproductive cycles in cattle, resulting in a delay in population increase. The ideal reproductive cycle in cattle raising is every 12 months (Paggasa, 2017). Disease prevention has been explained in article $41 \mathrm{~B}$ of Law No. 41 of 2014 concerning Animal Husbandry and Animal Health.

\section{Reduced Number of Productive Females}

The government prohibits the slaughtering of productive females because it will develop the next beef cattle population. However, farmers keep selling productive female cattle due to their financial needs. Article no. 18 of 2009 of Animal Husbandry and Animal Health paragraph (2) states the prohibition of female ruminants' slaughter except for research purposes or to tackle animal diseases. The prohibition provision does not apply if a sizeable female animal is: More than 8 (eight) years old or has given birth more than 5 (five) times; Unproductive, stated by the veterinarian or the staff of the reproduction technique assistant under the veterinary supervision; Have a severe accident; Suffering from a genetic defect that the offspring can inherit is not suitable for breeders; Contracted an infectious disease, which, according to the government, must be killed to eradicate and prevent the spread of the disease; Endanger human safety.

\section{Import Cattle}

The government is still implementing the meat import policy because of the government's inability to fulfill the meat needs of the community. According to Hasnudi (2009), a state can provide its meat if it can provide $90-95 \%$ itself, while the remaining $5-10 \%$ comes from imports. Beef prices increased due to scarce beef stocks in the market. Thus the government then imported meat from Australia. The decision to import cattle is approved only if domestic production and supply do not meet the people's consumption needs following Law (UU) No. 41/2014 concerning Animal Husbandry and Animal Health. Article 36 Paragraph 2 of Article 36 of Law No. 41/2014 is affirmed that livestock entry must be in the form of feeder cattle. The import decision is conducted because the government has difficulty in fulfilling domestic beef needs.

\section{Unfair Business Competition}

Decreased and insufficient beef cattle population will provide unfair competition, such as meat sales that do not meet quality standards. Examples of unfair competition are the emergence of beef meat modified to gain weight by imbibing the cow with lots of water daily to increase its size. This way is prohibited because it abuses animals, and the meat produced is of very low quality since it will affect meat freshness and result in the quick decaying of the meat.

\section{Limited Infrastructure Development Budget}

In beef cattle farming, it is important to support and facilitate the provision of animal feed, sales of results and mobility of activities carried out by both livestock groups and stakeholders. Most farmers in this area are faced with the challenge of having inadequate access to the road, under standard cage buildings, and limited animal feed processing facilities. This limitation is very closely related to limited capital control.

\section{Preparation of a SWOT Strategy}

Based on internal and external factors that influence the development of oil palm-cattle integration in the 
Bireuen district, was designed a strategy to utilize the strength and obtain opportunities (SO); utilize the strength to deal with threats (ST); reduce weaknesses by utilizing existing opportunities (WO) and strategies to reduce weaknesses in facing threats (WT). The SWOT strategy matrix for the development of oil palm-cattle integration can be seen in Table 2 .

Table 2 presented a combination of expert opinions that the integration model of oil palm-cattle will result in efficient value if the intensive model is implemented. Previous studies have presented a discussion on intensive models and their advantages. Government support will significantly determine the successful integration of oil palm cattle in the Bireuen district. The formation of pilot farmer/cattle breeder groups that have proven to be successful in developing oil palm-cattle integration has to become a strategic priority. If the pilot group is successful, it will easily pass on to other groups in various sub-districts with priority remaining in the sub-district that has already been analyzed and determined in the previous analysis. The internal factor of strength has the highest weighting value of 0.81 plus an external factor of opportunity with a weight value of 0.6 . When both combinations are adequately integrated, they influence the oil palm-cattle integration development, thereby improving the regional economy of the Bireuen district. Bireuen district will be the center of beef cattle farming with support from cattle breeder groups, academics, researchers and the government because it has all the potencies needed to establish beef cattle breeding centers in Aceh Province. The results of weighting the SWOT component can be seen in Table 3 .

The internal weakness factor has the smallest weighing value of 0.19 with an external factor threat value of 0.4 . They can be minimized by a strategy that has been built so that these two factors do not hamper the development of palm-cattle integration in Bireuen. Table 4 ranks the oil palm-cattle integration development strategy in Bireuen.

Table 2. The SWOT strategy matrix for the development of oil palm-cattle integration

\begin{tabular}{|c|c|c|}
\hline & Strengths: S1, S2, S3, S4, S5 & Weaknesses: W1, W2, W3, W4, W5, W6 \\
\hline \multirow[t]{4}{*}{$\begin{array}{l}\text { Opportunities: } \mathrm{O} 1, \mathrm{O} 2 \text {, } \\
\mathrm{O} 3, \mathrm{O} 4, \mathrm{O} 5\end{array}$} & $\begin{array}{l}\text { SO1 (S1, S2, S3, O1, O3, O5): Increases the } \\
\text { efficiency and effectiveness of oil palm-cattle } \\
\text { integration model from extensive to intensive } \\
\text { with stakeholder support }\end{array}$ & $\begin{array}{l}\text { WO1 }(\mathrm{W} 1, \mathrm{~W} 5, \mathrm{O} 5) \text { Increases the active role } \\
\text { of the government to facilitate cattle farmers } \\
\text { and plantations integration }\end{array}$ \\
\hline & $\begin{array}{l}\mathrm{SO} 2(\mathrm{~S} 2, \mathrm{~S} 3, \mathrm{~S} 4, \mathrm{O} 1, \mathrm{O} 4) \text { Form a group of pilot } \\
\text { livestock that will successfully carry out oil } \\
\text { palm-cattle integration by utilizing cheap and } \\
\text { nutritious feed from oil palm plantations }\end{array}$ & $\begin{array}{l}\text { Undertaking guiding of farming groups, } \\
\text { particularly on skill developments and } \\
\text { appropriate technology to increase land and } \\
\text { cattle productivities }\end{array}$ \\
\hline & $\begin{array}{l}\mathrm{SO} 3 \text { (S3, S5, O3) Utilizing cattle dung as } \\
\text { fertilizer and biogas as a source of income for } \\
\text { farmers }\end{array}$ & \\
\hline & $\begin{array}{l}\text { Increasing the role of government with rules/ } \\
\text { regulation with legal force in order to open the } \\
\text { opportunities the development of farming with } \\
\text { integrated system }\end{array}$ & $\begin{array}{l}\text { The government's direct participation, } \\
\text { especially in the inclusion of self-subsistent } \\
\text { production tools appropriate to the farmer's } \\
\text { needs, includes intensifying BUMG roles in } \\
\text { developing the groups. }\end{array}$ \\
\hline $\begin{array}{l}\text { Threats: } \mathrm{T} 1, \mathrm{~T} 2, \mathrm{~T} 3, \mathrm{~T} 4 \text {, } \\
\text { T5, T6 }\end{array}$ & $\begin{array}{l}\text { ST1 (S5, T2, T3, T4, T5) Increase breeders' } \\
\text { human resources for the development of beef } \\
\text { cattle population and livestock health services }\end{array}$ & $\begin{array}{l}\text { WT1 (W5, T3, T4, T5) Use Of financial } \\
\text { institutions/banking services to increase } \\
\text { business capital in increasing beef cattle } \\
\text { population and palm oil production }\end{array}$ \\
\hline
\end{tabular}


Table 3. Weighing of the SWOT components

\begin{tabular}{|c|c|c|c|c|}
\hline SWOT component & SWOT Factors & Weight & Rating & Total \\
\hline \multirow[t]{6}{*}{ Strengths } & The practice of cattle integration in the garden already exists & 0.15 & 4 & 0.6 \\
\hline & The width of oil palm plantation area & 0.3 & 4 & 1.2 \\
\hline & Population of beef cattle & 0.2 & 3 & 0.6 \\
\hline & The resources of cattle Farmers & 0.1 & 2 & 0.2 \\
\hline & Utilization of Cow Manure & 0.06 & 2 & 0.12 \\
\hline & Total & 0.81 & 15 & 2.72 \\
\hline \multirow[t]{8}{*}{ Weaknesses } & Farmer groups that focus on integration systems are very limited & 0.02 & 4 & 0.08 \\
\hline & Land ownership by farmers & 0.02 & 2 & 0.04 \\
\hline & Cow raising is extensive & 0.01 & 2 & 0.02 \\
\hline & Lack of knowledge and training for farmers & 0.1 & 3 & 0.3 \\
\hline & Limited access to capital and credit from financial institutions & 0.03 & 2 & 0.06 \\
\hline & Low integration system Efficiency & 0.01 & 2 & 0.02 \\
\hline & Total & 0.19 & 15 & 0.52 \\
\hline & Total Number & 1 & 30 & 3.24 \\
\hline \multirow[t]{5}{*}{ Opportunities } & Farmers get permission for plantation land & 0.13 & 4 & 0.52 \\
\hline & There is an artificial insemination program & 0.13 & 3 & 0.39 \\
\hline & The value of profits from oil palm-cattle integration & 0.12 & 3 & 0.36 \\
\hline & Availability of cheap feed from oil palm plantations & 0.12 & 4 & 0.48 \\
\hline & Total & 0.5 & 14 & 1.75 \\
\hline \multirow[t]{8}{*}{ Threaths } & Limited oil palm plantation industry & 0.14 & 3 & 0.42 \\
\hline & Disease / reproductive disorders. & 0.2 & 4 & 0.8 \\
\hline & Reduced productive females due to slaughtering & 0.02 & 3 & 0.06 \\
\hline & Import of cattle Production & 0.02 & 4 & 0.08 \\
\hline & Business competition & 0.01 & 2 & 0.02 \\
\hline & Limited infrastructure development budget & 0.01 & 2 & 0.02 \\
\hline & Total & 0.4 & 18 & 1.4 \\
\hline & Total Number & & 32 & 3.15 \\
\hline
\end{tabular}

Table 4. Ranking of directives for the development of palm-cattle integration

\begin{tabular}{llcc}
\hline SWOT Element No & Linkages & Number of Weights & Rank \\
\hline SO Strategy & & 1 & 1 \\
SO1 & S1, S2, S3, O1, O3, O5 & 0.85 & 2 \\
SO2 & S2, S3, S4, O1, O4 & 0.38 & 4 \\
SO3 & S3, S5, O3 & 0.4 & 3 \\
ST Strategy & S5, T2, T3, T4, T5 & & \\
ST1 & W1, W5, O5 & 0.15 & 5 \\
WO Strategy & & & \\
WO1 & W5, T3, T4, T5 & 0.06 & 6 \\
WT Strategy & & & \\
WT1 &
\end{tabular}

Strategies taken: SO1(Increasing the efficiency of the oil palm-cattle integration model from extensive to intensive with stakeholder support); SO2 (Form a pilot cattle breeder group that is successful in carrying out oil palm-cattle integration by utilizing cheap and nutritious feed from oil palm plantations); SO3 (Utilizing cow manure as fertilizer and biogas as a source of income for farmers); ST1 (Increase breeders' human resources for the development of beef cattle population and livestock health services); ST2 (The government's direct participation, especially in the inclusion of self-subsistent production tools appropriate to the farmer's needs, includes intensifying BUMG roles in developing the groups); WO1 (Increasing the active role of the government to facilitate farmers and cattle farmers in implementing integration); WT1 (Utilizing financial institutions/banking services to increase business capital in increasing beef cattle population and oil palm production). 


\section{Direction for Oil Palm-Cattle Integration Development in Increasing Regional Economy in Bireuen District}

The direction of the oil palm-cattle integration development is obtained based on the strategies already put in place. Principally, the developed strategies can be implemented in four sub-districts, as shown in Table 5. The development of oil palm-cattle integration is prioritized in Peusangan Siblah Krueng, South Peusangan and July sub-districts. In addition, some strategies areconducted so thatoilpalm-cattleintegration development can be evenly distributed throughout the districts in Bireuen, which have oil palm plantations. Therefore, the government needs to plan a good strategy in promoting the oil palm-cattle integration by taking into account all the internal and external factors that could dampen the implementation of oil palm-cattle integration. In Malaysia, the integration of oil palm cattle is implemented by combining the strengths and weaknesses of the oil palm-cattle integration system. Land use and practices of the palm oil industry can be sustainable (Assis et al. 2014).

The strategy with the highest value of weight is "increasing the efficiency of the maintenance model from extensive to intensive." There are advantages and disadvantages associated with the use of extensive and intensive models of beef cattle breeding. The selection of priority sub-districts in integrating oil-cattle activities is related to the government budget for implementing the activity. It is, therefore, essential to prioritize the development of the sub-districts to enable the various sub-districts to be focused on being fostered by the government and can be followed by other sub-districts. According to Ferdian et al. (2018), Factors that have a significant effect on production risks (risk-increasing factors) are forage feed and extension frequency in selfownership system, as well as concentrate variables in partnership system. Meanwhile, the factors that reduce the risk of beef cattle production (risk-reducing factors) include dummy cattle type, dummy livestock groups on the self-ownership system, and forage and labor variables on the partnership system.

The solid and liquid wastes from the palm oil - cattle in the integration system are mainly lingo-cellulosic compounds. They, therefore, have the potential to be converted to higher-value products such as biofuels, chemicals, and biomaterials. The development of cattle in the palm oil plantation area can be carried out by cow-calf operations using resources which consist of fronds, leaves, solid and palm kernel cake (Ahmad et al. 2019; Gunawan and Talib, 2014) with a potential capacity of two livestock units (LU) ) per ha (Mayulu et al. 2010).

It is also beneficial for the Bireuen District Government to refer to Kuantan Hilir District, which has developed a system of integration of the plantation and livestock sector through the Rubber-Oil Palm-Cattle system (Astuti and Putra, 2017). The system could be directly implemented in the form of agribusiness-based and agroindustry development plans. The first phase focused on providing production facilities and infrastructure as well as regional infrastructure. In contrast, the second phase focused on improving and strengthening the socio-economic structure to support and increase the regional development and competitiveness of the region (Mohd and Norsida, 2014; Soedjana and Priyanti, 2017). Moreover, partnership with financial institutions/ banking services to increase business capital in increasing beef cattle population and oil palm production is an important priority. According to Asante et al. (2018), technical efficiency in system integration of oil palm plantation-cattle breeding is strongly influenced by the ease of access to fund credit.

\section{Managerial Implications}

An important implication of this research is to increase the opportunities for regional development that combines the potential of agriculture and animal husbandry while maximizing the optimization of land use for oil palm plantations, which so far have not been widely used for other than agriculture. In addition, this research will have a broad impact on increasing the fulfillment of local protein sources so that it can reduce the volume of meat imports on a regional scale, increase people's income, increase regional GRDP.

\section{CONCLUSIONS AND RECOMMENDATIONS}

\section{Conclusions}

To effectively and efficiently support the success of oil palm-cattle integration program in prioritized sub-district in Bireuen region, six main strategies are required: 1) Improving the efficiency of oil palmcattle integration model from extensive to intensive with the support of stakeholders; 2) Creating effective 
and successful pilot livestock groups in carrying out oil palm-cattle integration by utilizing cheap and nutritious feed from oil palm plantations; 3) Utilizing cow dung as fertilizer and biogas as a source of income for farmers; 4) Increasing breeders' human resources for the development of beef cattle population and livestock health services; 5) Increasing the active participation of government to facilitate cattle farmers and plantations in implementing integrations; and 6) Utilizing financial institutions/banking services to increase business capital, which will aid in increasing beef cattle population and oil palm production.

\section{Recommendations}

To maximize the potential for integration of oil palmcattle in the Bireuen district, strong support from the government and other stakeholders is needed for existing farmer groups. The support needed is to increase the capacity of human resources and facilitate access to financing to increase business capital. In addition, local governments can contribute more significantly by issuing local regulations that support this program.

\section{REFERENCES}

Ahmad FB et al. 2019. The outlook of the production of advanced fuels and chemicals from integrated oil palm biomass bio-refinery. Renewable and Sustainable Energy Reviews 109: 386-411. https://doi.org/10.1016/j.rser.2019.04.009.

Asante BO et al. 2018. Performance of integrated crop-small ruminant production systems in West Africa. Agroforest System 99(3): 989-999. https://doi.org/10.1007/s10457-018-0196-8.

Asante BO, Villano RA, Battese GE. 2017. Integrated Crop-Livestock Management Practices, Technical Efficiency and Technology Ratios in Extensive Small-Ruminant Systems in Ghana, Livestock Science 201: 58-69. http://dx.doi. org/10.1016/j.livsci.2017.03.010.

Assis K et al. 2014. Perception of Oil Palm Estate Managers towards Oil Palm-Cattle Integration. International Journal of Science Commerce and Humanities 2(3):33-38.

Astuti P, Putra FA. 2017. Development of Agropolis Region Based on Integrated Plantations and Livestock through Concept of KARSSA (Rubber Palm Oil Beef Cattle) in Kuantan Hilir District. Prosiding $2^{\text {nd }}$ Celscitech UMRI. 2(2017): 2-17.
Retrieved from http://ejurnal.umri.ac.id/index. php/PCST/article/view/278/227

Ayob MA, Kabul MA. 2009. Cattle Integration in Oil Palm Plantation through Systematic Management. The 1st International Seminar on Animal Industry Bogor, 23-24 November 2009. Retrieved from https://www.researchgate.net/ publication/267726937

BKPM. 2016. Komoditas Unggulan Daerah. Retrieved from http://regionalinvestment.bkpm.go.id/ newsipid/id/commodityarea.php?ia=11\&ic=2.

Badan Pusat Statistik [BPS]. 2017. Provinsi Aceh dalam Angka. BPS Provinsi Aceh

Badan Pusat Statistik [BPS]. 2017. Kabupaten Bireuen dalam Angka. BPS Kabupaten Bireuen

Devendra C. 2009. Intensification of integrated oil palm-ruminant systems: Enhancing increased productivity and sustainability in South-east Asia. Outlook on Agriculture 38(1):71-81.

Devendra C. 2004. Integrated tree crops- ruminants systems: Potential importance of the oil palm. Outlook on Agriculture 33(3):157-166.

Devendra C. 2011. Integrated Tree Crops-ruminants Systems in South East Asia: Advances in Productivity Enhancement and Environmental Sustainability. Asian-Australasian Journal of Animal Sciences 24(5): 587-602. http://dx.doi. org/10.5713/ajas.2011.r.07

De Pinto A et al. 2016. Low Emission Development Strategies in Agriculture. an Agriculture, Forestry, and Other Land Uses (AFOLU) Perspective. World Development 87: 180-203. http://dx.doi. org/10.1016/j.worlddev.2016.06.013

Ferdian A, Mulyo JH, Masyhuri, Subejo. 2018. Risk production analysis of small-scale beef cattle farmers in the special region of Yogyakarta, Indonesia. IOSR Journal of Agriculture and Veterinary Science 11(9):35-42. http://dx.doi. org/ 10.9790/2380-1109023542.

Gabdo BH, Ismail A. 2013. Analysis of the benefits of livestock to oil palm in anintegrated system: evidance from selected districts in Johor, Malaysia. Journal of Agricultural Science 5(12): 48-55.

Gunawan, Talib C. 2014. Potensi pengembangan bioindustri dalam sistem integrasi sapi sawit. WARTAZOA 24(2):67-74. http://dx.doi. org/10.14334/wartazoa.v24i2.1050

Gutiérrez-Vélez VH, DeFries R, Pinedo-Vásquez M. 2011. High-yield oil palm expansion spares land at the expense of forests in the Peruvian Amazon. 
Environmental Research Letters 6:44029. doi:10.1088/1748-9326/6/4/044029

Hanifah VW, Wasito. 2018. Perception on integration of food crops and livestock in oil palm plantation to reach bioindustrial agriculture model: case in north Sumatra Provinsi, Indonesia. Journal of Science, Technology and Innovation Policy 4(2): $1-8$.

Hasnudi. 2009. Kajian Kelayakan Pembentukan Sentra Peternakan Sapi Terpadu di Sumatera Utara (Studi Kasus di Kabupaten Langkat). Medan: Badan Penelitian dan Pengembangan Provinsi Sumatera Utara.

Henuk YL et al. 2018. The integrated farming systems between cattle and oil palm plantation in Indonesia. $17^{\text {th }}$ ADRI International Conference Retrieved from https://www.researchgate.net/ publication/327662867

Henson IE, Ruiz R, Romero HM. 2012. The greenhouse gas balance of the oil palm industry in Colombia: A preliminary analysis. I. Carbon sequestration and carbon offsets. Agronomia Colombiana 30 (3): 359-369.

Jalaludin S. 2018. Integrated animal production in the oil palm plantation. Retrieved from http:// www.fao.org/livestock/AGAP/frg/conf96.htm/ jalaludi.htm.

Ministry of Agriculture. 2015. Ministry of Agriculture Strategic Plan 2015-2019.

Latif J, Mamat MN. 2002. A financial study of cattle integration in oil palm plantations. Oil Palm Industry Economic Journal 2(1): 34-44.

Lerner AM et al. 2017. Sustainable cattle ranching in practice: moving from theory to planning in colombia's livestock sector. Environmental Management http://dx.doi.org/10.1007/s00267017-0902-8

Lim HC, Ayob MA, Mat K. 2019. Stakeholders' perception towards participation in cattle - oil palm integration projects. Canadian Social Science 15 (8): 36-40. http://dx.doi.org/ 10.3968/11251.

Martin S et al. 2015. Small farmers and sustainability: Institutional barriers to investment and innovation in the Malaysian palm oil industry in Sabah. Journal of Rural Studies 40:46-58. http://dx.doi. org/10.1016/j.jrurstud.2015.06.002.

Mathius IW,AdiatiU.2013.Bahan OrganikAsalKotoran Sapi Sebagai Titik Ungkit Pengembangan Sapi Potong Dalam Kawasan Industri Sawit. Model
Pengembangan Sistem Integrasi Tanaman-Sapi Berbasis Inovasi. Jakarta: IAARD Press.

Matondang RS, Talib C. 2015. Model pengembangan sapi bali dalam usaha integrasi di perkebunan kelapa sawit. WARTAZOA 25(3): 147-157.http:// dx.doi.org/10.14334/wartazoa.v25i3.1159.

Mayulu H, Sunarso, Sutrisno CI, Sumarsono. 2010. Kebijakan pengembangan peternakan sapi potong di Indonesia. Jurnal Litbang Pertanian 29:34-41.

Mohd Said MF, Norsida M. 2014. Evaluation of target area concentration (tac) programme in malaysia's integrated cattle and oil palm farming. Journal of Food Products Marketing 20:151-163. http:// dx.doi.org/10.1080/10454446.2014.921870.

Paggasa Y. 2017. Model usaha ternak integrasi sawitternak sapi potong di P4S Cahaya Purnama Kecamatan Bengalon Kabupaten Kutai Timur. Jurnal Pertanian Terpadu 5(1): 117128.

Paris TR. 2002. Crop-animal systems in Asia: socio-economic benefits and impacts on rural livelihoods. Agricultural Systems 71(1): 147-168. https://doi.org/10.1016/S0308521X(01)00041-5

Rahman AA et al. 2018. Adoption of Integrated Farming System of Cattle and Oil Palm Plantation in Malaysia. Advanced Science Letters 24(4): 2281. DOI: https://doi.org/10.1166/asl.2018.10935.

Rahutomo S et al. 2012. Integrasi Sawit, Sapi dan Energi. Medan: Pusat Penelitian Kelapa Sawit (PPKS)

Silalahi FRL, Rauf A, Hanum C, Siahaan D. 2018. The characteristic and problems of beef cattle-palm oil integration in Indonesia. IOP Conf. Ser.: Earth Environ. Sci. 205012016

Silalahi FRL, Rauf A, Hanum C, Siahaan D. 2019. SWOT analysis of development of beef cattle - palm oil integration in Indonesia. IOP Conf. Ser.: Earth Environ. Sci. 347012105

Soedjana TD, Priyanti R. 2017. Competitiveness of Indonesian Livestock Production among ASEAN Countries. WARTAZOA 27(1): 1-14. http://dx.doi.org/10.14334/wartazoa.v27i1.1411

Tohiran KA et al. 2017. Targeted cattle grazing as an alternative to herbicides for controlling weeds in bird-friendly oil palm plantations. Agronomy for Sustainable Development 37:62. https://doi. org/10.1007/s13593-017-0471-5.

Tohiran KA et al. 2019. Cattle-grazing in oil palm 
plantations sustainably controls understory Vegetation. Agriculture, Ecosystems and Environment 278 (2019) 54-60. https://doi. org/10.1016/j.agee.2019.03.021
Utomo BN, Widjaja E. 2012. Development of beef cattle based on oil palm industry. Jurnal Penelitian dan Pengembangan Pertanian 31(4): 153-161. 